ISSN 1392-3196

Zemdirbyste-Agriculture, vol. 100, No. 1 (2013), p. 25-32

UDK 631.4:631.582:632.51 / DOI 10.13080/z-a.2013.100.004

\title{
The influence of primary soil tillage on soil weed seed bank and weed incidence in a cereal-grass crop rotation
}

\author{
Regina SKUODIENE ${ }^{1}$, Danute KARČAUSKIENE ${ }^{1}$, Steponas ČIUBERKIS ${ }^{1}$, \\ Regina REPŠIENË ${ }^{1}$, Dalia AMBRAZAITIENË $\dot{1}^{1,2}$ \\ ${ }^{1}$ Vèžaičiai Branch, Lithuanian Research Centre for Agriculture and Forestry \\ Gargždu 29, Vèžaičiai, Klaipėda distr., Lithuania \\ E-mail: rskuod@vezaiciai.lzi.lt \\ ${ }^{2}$ Klaipèda University \\ H. Manto 84, Klaipėda, Lithuania
}

\begin{abstract}
A field experiment was carried out at Vèžaičiai Branch of Lithuanian Research Centre for Agriculture and Forestry during the period 2008-2011. The study was aimed to determine the effects of various soil tillage methods: deep ploughing $(20-25 \mathrm{~cm})$, shallow ploughing $(10-12 \mathrm{~cm})$, shallow ploughless tillage $(8-10 \mathrm{~cm})$ and soil fertility improvement measures (plant residues, plant residues + straw, green manure $1^{\text {st }}$ cut + straw, green manure $2^{\text {nd }}$ cut + straw, farmyard manure $40 \mathrm{t} \mathrm{ha}^{-1}+$ straw) on the soil weed seed bank and weed incidence in a cereal-grass crop rotation. The soil of the experimental site is Dystric-Epihypogleyic Albeluvisol (ABg-p-w-dy) with a texture of sandy loam.

In all experimental years, primary soil tillage had a significant influence on weed incidence in the crops of the rotation and on soil weed seed bank. The greatest amount of weeds, both in numbers and dry mass, in the crops of winter triticale and spring rape was determined in the shallow ploughless tillage treatment, in the crops of spring barley in the shallow ploughing treatment, and in the sward of red clover in deep and shallow ploughing treatments. All soil fertility improvement measures and their interaction with soil tillage methods did not have any substantial influence on the weed incidence in the rotation crops. The soil weed seed bank was 1.5 and 2.2 times greater in the shallow ploughing and shallow ploughless tillage treatments, compared with the conventional tillage treatment (deep ploughing). The influence of soil tillage methods manifested itself not only directly, but also through its interaction with soil fertility improvement measures. Regardless of the chosen soil fertility improvement measure, in all the treatments of shallow ploughless tillage, the soil weed seed bank was significantly greater, compared with the conventional soil tillage treatments.

In the shallow ploughing and shallow ploughless tillage treatments there were found $25.5 \%$ and $41.5 \%$ more weed seed species in the soil, compared with the conventional tillage treatment. The seeds of Chenopodium album L., Persicaria lapathifolia L., Fallopia convolvulus L. and Viola arvensis Murray were found in all tillage treatments. The distribution of F. convolvulus L., P. lapathifolia L. seeds was significantly influenced by soil tillage only, that of $V$. arvensis Murray by soil tillage and its interaction with soil fertility improvement measures, and that of Ch. album L. by soil fertility improvement measures only.
\end{abstract}

Key words: amount and mass of weeds, autumn soil tillage, crop rotation, seed bank, soil fertility improvement measures.

\section{Introduction}

Weed incidence in field crops has been comprehensively investigated in Lithuania and abroad. Numerous studies have indicated that soil nutrient status, crop rotation and its structure, as well as soil tillage system influence weed incidence in crops. Researchers have highlighted the importance of creating optimum growth and development conditions for crop rotation plants. With declining soil acidity, the number of acid-loving weeds consistently decreased (Čiuberkis, 2009), while the total number of weeds significantly $\left(r=0.84-0.96^{* *}\right)$ depended on the amount of available aluminium in the soil (Skuodienè, Repšienè, 2009). When improving the soil with organic fertilizers, all organic fertilizers were found to increase the weed incidence in cereal crops, but manure increased it more than the biomass of legumes incorporated into the soil as green manure (Arlauskienè, Maikštènienè, 2005).

Shallow ploughing promoted the spread of weeds (Stancevičius et al., 1996; Čiuberkis, 2008). In a light loam soil, the number of annual weeds increased in ploughed treatments compared with reduced tillage treatments. The number of perennial weeds and air dried mass were substantially greater in the crops of spring wheat and spring rape in the direct drilling treatment, 
compared with ploughing treatment (Deveikyte et al., 2008). In a clay loam soil, the application of noninversion soil tillage for two years in succession resulted in a decrease in annual weeds and an increase in perennial weeds (Velykis, Satkus, 2003).

The weed seed bank is the main source of weeds in agricultural fields. Soil weed seed banks are reserves of viable seeds present on the surface and in the soil. The seed bank consists of new seeds recently shed by a weed plant as well as older seeds that have persisted in the soil for several years. The seed bank is an indicator of past and present weed populations. There are enormous numbers of viable weed seeds in the soil. Although a great number of the buried seeds die within a few years, seeds of some species can remain viable for decades. It has been estimated that only $1-9 \%$ of the viable seeds produced in a given year develop into seedlings; the rest remain viable and will germinate in subsequent years depending on the depth of their burial (Swanton et al., 2000). Seeds are dispersed both horizontally and vertically in the soil profile. The greatest seed reserves were in the surface layer $(0-5 \mathrm{~cm})$ of the soil (Gselman, Kramberger, 2004; Janicka, 2006).

Soil tillage has a significant influence on the dynamics of weed seeds (Moonen, Barberi, 2004). The highest number of weed seed species was found in the treatments with reduced and no-tillage treatments in a soil layer of $0-5 \mathrm{~cm}$. In deeper soil layers (5-10, $10-20 \mathrm{~cm}$ ), no differences in weed seed species number were found (Auškalnienè, Auškalnis, 2009). The tillage system influenced weed seed bank size and composition to a much greater extent than crop rotation. Crop rotation did not influence either weed seed bank size or seedling distribution among soil layers, and only had a small influence on major species abundance (Bàrberi, Lo Cascio, 2001). Weeds are not only the indicators of ecological conditions, but also they show the degree of soil cultivation.

The aim of the current research was to determine the impact of various soil primary tillage methods and soil fertility improvement measures on soil weed seed bank and weed incidence in a cereal-grass crop rotation.

\section{Materials and methods}

Site and soil description. The soil of the experimental site is Dystric Epihypogleyic Albeluvisol $(A B g-p-w-d y)$ with a texture of sandy loam (clay particles $<0.002 \mathrm{~mm}-13-15 \%$ ), whose $\mathrm{pH}$ at the beginning of the trial was 5.1-5.3. The soil is moderate in humus status (humus $-2.43 \%$, organic carbon $-1.41 \%$ ), moderate in phosphorus content and high in potassium (106 and $270 \mathrm{mg} \mathrm{kg}^{-1}$ soil, respectively).

The trial was established in 2003 in the experimental field of crop rotation of Véžaičiai Branch of Lithuanian Institute of Agriculture (currently - Véžaičiai Branch of Lithuanian Research Centre for Agriculture and Forestry). In 2007, the trial was continued for the second crop rotation by sowing winter triticale in the autumn. The four-course crop rotation consisted of winter triticale (Triticosecale Wittm) 'SW Talentro' sown at a seed rate of 5.5 million ha ${ }^{-1}$ (2008), spring rape (Brassica napus L. ssp. oleifera annua Metzq) 'Lindmark' sown at a seed rate of $8.0 \mathrm{~kg} \mathrm{ha}^{-1}$ (2009), spring barley (Hordeum vulgare L.) 'Luokè' sown at a seed rate of 4.0 million ha-1 undersown with red clover at a seed rate of $14.0 \mathrm{~kg} \mathrm{ha}^{-1}$ (2010), red clover (Trifolium pratense L.) 'Liepsna' of the first year of use (2011). The total plot size amounted to $20 \times 5=100 \mathrm{~m}^{2}$. The harvested area for cereals and rape amounted to $16 \times 2.2=35.2 \mathrm{~m}^{2}$ and for clover $16 \times$ $1.4=22.4 \mathrm{~m}^{2}$. The trial was replicated four times.

Trial factors and treatments. Factor A - primary soil tillage (in autumn): 1) deep ploughing (20-25 cm), 2) shallow ploughing $(10-12 \mathrm{~cm}), 3)$ shallow ploughless tillage $(8-10 \mathrm{~cm})$; factor $\mathrm{B}-$ soil fertility improvement measures: 1) plant residues (R), 2) plant residues + straw $(\mathrm{R}+\mathrm{S}), 3)$ green manure $1^{\mathrm{st}}$ cut + straw $\left.(\mathrm{GI}+\mathrm{S}), 4\right)$ green manure $2^{\text {nd }}$ cut + straw $\left.(\mathrm{GII}+\mathrm{S}), 5\right)$ farmyard manure 40 t ha $^{-1}+$ straw $(\mathrm{M}+\mathrm{S})$.

In 2007, the phytomass of red clover was incorporated into the soil according to the scheme of factor B. The phytomass of clover was removed from the plots of the first, the second, and the fifth treatments. The phytomass of clover from the plots of the third and the fourth treatments was spread: $3.2 \mathrm{t} \mathrm{ha}^{-1}$ dry matter (DM) of the $1^{\text {st }}$ cut and $2.2 \mathrm{tha}^{-1} \mathrm{DM}$ of the $2^{\text {nd }}$ cut, respectively. In the plots of the fifth treatment $40 \mathrm{tha}^{-1}$ manure was spread. Organic fertilizers were incorporated with a disc stubble cultivator. After three weeks, the plots of the first treatment, of factor A were deeply ploughed with a plough fitted with semi screw blades; those of the second treatment were shallow ploughed, and the plots of the third treatment were cultivated with a spring-tine cultivator, applying shallow ploughless tillage. Before sowing, the soil was cultivated with a pre-sowing soil tillage cultivator and on the $17^{\text {th }}$ of September the winter triticale 'SW Talentro' was sown with a disc seed drill "Fiona SD-977" ("Fiona Maskinfabrik A/S", Denmark).

In 2008, after winter triticale harvesting, in the first treatment of factor $B$, the straw was removed from the plots; the straw $\left(8.9 \mathrm{t} \mathrm{ha}^{-1}\right)$ of the second-fifth treatments was chopped at harvesting with a combine harvester "Sampo 500" ("Sampo Rosenlew", Finland) and spread in the plots. A rate of $10 \mathrm{~kg}$ nitrogen (calcium ammonium nitrate) was applied per ton of straw. To prevent soil acidification and to compensate for the loss of calcium which is leached from the soil and is removed with the yield, $400 \mathrm{~kg} \mathrm{ha}^{-1}$ lime fertilizers (in 2007 dolomite and in 2008 limestone dust) were applied throughout the whole experimental area; lime fertilizers and straw were incorporated with a disc stubble cultivator. In 2008 and in the autumn of 2009, the soil was cultivated according to the experimental design. The crops of the rotation, except for clover, were sprayed with herbicides. To protect the record sites, they were covered with a polyethylene film.

The spring in 2009 was early. Warm and normally humid weather prevailed in March and May, while April was dry. There was a shortage of moisture during the spring rape emergence. In summer, the weather was warm and normally wet. The conditions were favourable for the growth of spring rape and weeds.

The spring in 2010 was late. In April, not cold and dry weather prevailed, and in May it was warm and rainy. Adequate soil moisture and warm weather had a positive influence on the germination of spring barley and weeds and their further growth in June. The rainy weather of June was replaced by a heat wave in July. 
The compacted soil dried off and cracked. The moisture content at a depth of seedbed on July 12 was $5.9-7.5 \%$, which is below the plant wilting humidity. Although the amount of rainfall that fell during the summer was $43 \%$ higher than the long-term mean, its distribution was very uneven. The growth and development conditions for the spring barley and under-sown red clover were satisfactory. For the greater part of September the weather was moderately warm and rainy. Growing conditions for red clover were good. Although the cold weather of October and November prompted the plans for better wintering preparation, very low temperatures in February 2011 damaged clover, especially at the hilltops and waterlogged places. In spring, the prevailing weather was dry (in March the precipitation was $40 \%$, in April $-93 \%$ and in May - $85 \%$ of the long-term mean). The average air temperature of spring period was close to the long-term mean. The growing conditions for red clover were satisfactory.

The experimental data were analysed by a twofactor analysis of variance recommended in agronomy science. Significance of the differences between the means was determined according to the least significant difference (LSD) at 0.05 probability level. The data were processed using software ANOVA (Tarakanovas, Raudonius, 2003).

\section{Results and discussion}

The weed incidence in the crop rotation. Phytocenoses are not constant. They change in response to changing environmental conditions and different agricultural practices. Analysis of weed incidence in separate crops of the rotation shows that in 2008 the prolonged drought lasting from April 20 to June 16 (57 days with the amount of precipitation as low as $15.6 \mathrm{~mm}$ ) resulted in a low weed incidence in the crops of winter triticale (Table 1). Literature sources indicate that weed incidence in field crops is determined by meteorological conditions, especially the amount of precipitation in spring (Auškalnienè, 2006; Deveikytè et al., 2008) and soil moisture (Jursík et al., 2010). Analysis of variance indicated that soil tillage method had a significant impact on the weed incidence in winter triticale crops (the amount of weeds $\mathrm{F}_{\text {act. }}=7.46>\mathrm{F}_{\text {tabl. } .0 .1}=5.15$ and their dry matter mass $\mathrm{F}_{\text {act. }} \stackrel{\text { act. }}{=} 6.00>\mathrm{F}_{\text {tabl.0.1 }} \stackrel{=}{=} .15$, respectively). The significantly greatest number of weeds $11.1 \mathrm{~m}^{-2}$ was determined in the treatment of shallow ploughless tillage. In the deep and shallow ploughing treatments, the amount of weeds in the crops of winter triticale was 1.5 times lower than in the shallow ploughless tillage treatment. This could be influenced by the soil moisture because the topsoil layer in shallow ploughed and shallow tilled soil was by $2-3$ percentage points wetter, compared to the deep ploughed soil.

Table 1. The effect of primary soil tillage and soil fertility improvement measures on the weed incidence in the crop rotation

\begin{tabular}{|c|c|c|c|c|c|c|c|c|}
\hline \multirow{3}{*}{ Treatment } & \multicolumn{2}{|c|}{$\begin{array}{c}\text { Winter triticale } \\
2008 \\
\end{array}$} & \multicolumn{2}{|c|}{$\begin{array}{c}\text { Spring rape } \\
2009\end{array}$} & \multicolumn{2}{|c|}{$\begin{array}{c}\text { Spring barley } \\
2010\end{array}$} & \multicolumn{2}{|c|}{$\begin{array}{c}\text { Red clover } \\
2011\end{array}$} \\
\hline & \multicolumn{8}{|c|}{ Weediness } \\
\hline & $\begin{array}{c}\text { plants } \\
\mathrm{m}^{-2}\end{array}$ & $\begin{array}{c}\text { mass of } \\
\text { DM } \\
\mathrm{g} \mathrm{m}^{-2}\end{array}$ & $\begin{array}{c}\text { plants } \\
\mathrm{m}^{-2}\end{array}$ & $\begin{array}{c}\text { mass of } \\
\text { DM } \\
\mathrm{g} \mathrm{m}^{-2}\end{array}$ & $\underset{\mathrm{m}^{-2}}{\text { plants }}$ & $\begin{array}{c}\text { mass of } \\
\text { DM } \\
\mathrm{g} \mathrm{m}^{-2}\end{array}$ & $\underset{\mathrm{m}^{-2}}{\text { plants }}$ & $\begin{array}{c}\text { mass of } \\
\text { DM } \\
\mathrm{g} \mathrm{m}^{-2}\end{array}$ \\
\hline \multicolumn{9}{|c|}{ Primary soil tillage (factor A) } \\
\hline Deep ploughing & 7.6 & 14.8 & 49.6 & 106.1 & 39.1 & 16.0 & 192.4 & 50,8 \\
\hline Shallow ploughing & 7.5 & 14.1 & 48.4 & 102.1 & 46.2 & 19.8 & 174.8 & $39.9^{*}$ \\
\hline Shallow ploughless tillage & $11.1 * *$ & $23.3 * *$ & $79.7 * *$ & $173.3 * *$ & $22.7 * *$ & 10.6 & $159.0^{*}$ & 48.5 \\
\hline $\mathrm{LSD}_{05}$ & 2.187 & 5.925 & 25.351 & 53.174 & 10.881 & 5.836 & 32.213 & 10.734 \\
\hline \multicolumn{9}{|c|}{ Soil fertility improvement measures (factor B) } \\
\hline Plant residues & 9.3 & 15.1 & 61.6 & 122.3 & 31.7 & 15.2 & 167.9 & 42.2 \\
\hline Plant residues + straw & 8.5 & 19.6 & 61.2 & 126.9 & 43.7 & 15.3 & $195.3^{*}$ & 45.8 \\
\hline $\begin{array}{l}\text { Green manure } \\
1^{\text {st }} \text { cut }+ \text { straw }\end{array}$ & 8.3 & 17.4 & 57.9 & 128.2 & 31.5 & 12.1 & 177.7 & 43.4 \\
\hline $\begin{array}{l}\text { Green manure } \\
2^{\text {nd }} \text { cut }+ \text { straw }\end{array}$ & 9.5 & 17.6 & 57.2 & 131.8 & 36.5 & 19.0 & 153.3 & 49.9 \\
\hline $\begin{array}{c}\text { Farmyard manure } \\
40 \mathrm{t} \mathrm{ha}^{-1}+\text { straw }\end{array}$ & 8.0 & 17.4 & 58.2 & 126.8 & 36.7 & 15.9 & 182.7 & 50.7 \\
\hline $\mathrm{LSD}_{05}$ & 2.823 & 7.649 & 14.356 & 12.965 & 14.047 & 7.534 & 41.586 & 13.857 \\
\hline \multicolumn{9}{|c|}{ Interaction of factors $\mathrm{A}$ and $\mathrm{B}$} \\
\hline $\mathrm{A} 1 \times \mathrm{B} 1$ & 9.8 & 12.7 & 52.2 & 92.6 & 39.0 & 14.2 & 147.0 & 38.5 \\
\hline $\mathrm{A} 1 \times \mathrm{B} 2$ & 7.0 & 19.6 & 47.2 & 107.5 & 43.0 & 13.3 & $257.0 * *$ & 53.7 \\
\hline $\mathrm{A} 1 \times \mathrm{B} 3$ & 8.0 & 12.4 & 48.5 & 105.1 & 34.5 & 7.8 & 204.0 & 58.8 \\
\hline $\mathrm{A} 1 \times \mathrm{B} 4$ & 6.8 & 13.2 & 48.8 & 114.5 & 48.0 & $31.0 *$ & 160.0 & 56.3 \\
\hline $\mathrm{A} 1 \times \mathrm{B} 5$ & 6.2 & 16.2 & 51.2 & 110.9 & 31.0 & 14.0 & 194.0 & 46.9 \\
\hline $\mathrm{A} 2 \times \mathrm{B} 1$ & 7.5 & 15.4 & 54.5 & 106.2 & 31.5 & 16.4 & 191.0 & 37.0 \\
\hline $\mathrm{A} 2 \times \mathrm{B} 2$ & 6.0 & 15.0 & 48.5 & 100.6 & $66.0^{*}$ & 19.3 & 154.0 & 39.1 \\
\hline $\mathrm{A} 2 \times \mathrm{B} 3$ & 6.8 & 16.9 & 45.0 & 106.6 & 42.0 & 21.4 & 163.0 & 30.6 \\
\hline $\mathrm{A} 2 \times \mathrm{B} 4$ & 8.8 & 11.4 & 48.2 & 101.9 & 38.5 & 17.4 & 180.0 & 48.9 \\
\hline $\mathrm{A} 2 \times \mathrm{B} 5$ & 8.5 & 11.8 & 45.8 & 95.0 & 53.0 & 24.7 & 186.0 & 43.8 \\
\hline $\mathrm{A} 3 \times \mathrm{B} 1$ & 10.8 & 17.2 & 78.0 & $168.0^{*}$ & 24.5 & 15.0 & 165.8 & 51.2 \\
\hline $\mathrm{A} 3 \times \mathrm{B} 2$ & 12.5 & 24.0 & 87.8 & $172.5^{*}$ & 22.0 & 13.2 & 175.0 & 44.5 \\
\hline $\mathrm{A} 3 \times \mathrm{B} 3$ & 10.2 & 22.7 & 80.2 & $172.8 *$ & 18.0 & 7.0 & 166.0 & 40.9 \\
\hline $\mathrm{A} 3 \times \mathrm{B} 4$ & 13.0 & 28.2 & 74.8 & $178.9 *$ & 23.0 & 8.6 & 120.0 & 44.6 \\
\hline \multirow[t]{2}{*}{$\mathrm{A} 3 \times \mathrm{B} 5$} & 9.2 & 24.3 & 77.8 & $174.4^{*}$ & 26.0 & 8.9 & 168.0 & 61.5 \\
\hline & 4.890 & 13.248 & 45.312 & 36.735 & 24.330 & 13.050 & 72.030 & 24.001 \\
\hline
\end{tabular}

DM - dry matter; * - significant at $P<0.05$, and ** - significant at $P<0.01$ 
The weed incidence did not depend on the soil fertility improvement measures. The differences were not significant.

The interaction of these two factors did not have any influence on the weed incidence in winter triticale either. Similar trend was found for dry matter mass of weeds. The significantly greatest $\left(23.3 \mathrm{~g} \mathrm{~m}^{-2}\right)$ mass of weed dry matter was determined in the shallow ploughless tillage treatment. Different soil fertility improvement measures and their interaction with soil tillage methods did not have any significant influence. However, it was noted that weed dry matter mass was $15-30 \%$ greater when shallow ploughless tillage and the phytomass of red clover or manure for the improvement of soil fertility had been applied compared with only plant residues' usage. According to Menalled et al. (2001), aboveground weed biomass, species density, and diversity were lowest in the conventional system, intermediate in the no-till system, and highest in the low-input and organic systems, but there were significant year-by-system interactions.

Soil tillage methods in the autumn had a significant influence on the weed incidence in spring rape crops. Significantly greatest number of weeds and their dry matter mass was determined in the shallow ploughless tillage treatment (79.7 weeds $\mathrm{m}^{-2}$ and $173.3 \mathrm{~g}$ $\mathrm{m}^{-2}$, respectively) (Table 1). Having used deep and shallow ploughing, the amount of weeds and their dry matter mass in spring rape crops was 1.6-1.7 times lower compared with shallow ploughless tillage. The weed incidence did not depend on the soil fertility improvement measures. The differences were not significant. The interaction of these two factors did not have any influence on the weed incidence in crops either. Regardless of the chosen soil fertility improvement measure, in all shallow ploughless tillage treatments weed dry matter mass was significantly greater (168.0-178.9 $\mathrm{g} \mathrm{m}^{-2}$ ) in comparison with shallow ploughing and conventional soil tillage methods.

In July 2010, the rainy weather of June was replaced by a heat wave (the mean air temperature within $11^{\text {th }}-17^{\text {th }}$ rose to $24.0^{\circ} \mathrm{C}$ and there was no rainfall within $\left.1^{\text {st }}-13^{\text {th }}\right)$, which resulted in a low weed incidence in the crops of spring barley. Soil tillage method had a significant influence on the amount of weeds and their dry matter mass, respectively $\mathrm{F}_{\text {act. }}=9.99>\mathrm{F}_{\text {tabl.0.1 }}=5.15$ and $\mathrm{F}_{\text {act. }}$ $=5.21>\mathrm{F}_{\text {tabl. } 0.1}=5.15$. The significantly lowest amount of weeds and their dry matter mass was determined in the shallow ploughless tillage treatment (22.7 weeds $\mathrm{m}^{-2}$ and $10.6 \mathrm{~g} \mathrm{~m}^{-2}$, respectively) (Table 1 ), where barley suppressed weeds better compared with deep and shallow ploughing. In terms of moisture preservation, the minimal soil tillage is superior to the conventional deep ploughing (Velykis, Maikštèniene, 1995; Šimanskaite, 2002).

The weed incidence in crops did not depend on the soil improvement measures. The differences were not significant. Red clover, which was the last course of the crop rotation sequence, formed a thinner sward after the cold winter. In such a lawn the sown plants are more exuberant; however, the conditions within such a lawn are favourable for weed species, especially those tolerant of shade and preferring wet environments. Weeds were numerous but small in the sward of red clover. The highest amount of weeds and their dry matter mass 192.4 plants $\mathrm{m}^{-2}$ and $50.8 \mathrm{~g} \mathrm{~m}^{-2}$ respectively was determined in the deep ploughing treatment (Table 1). The weed incidence did not depend on the different soil fertility improvement measures. The differences were not significant. Because of the interaction of deep ploughing and plant residues + straw used as soil fertility improvement measure the amount of weeds was significantly higher.

In order to compare the species composition of the weed seed bank with the weed species composition in the last course of the rotation sequence - red clover sward, the weeds in the red clover sward were divided into families. The weeds identified in the different soil tillage treatments of red clover swards belonged to 11 families: Asteraceae, Boraginaceae, Brassicaceae, Caryophyllaceae, Chenopodiaceae, Plantaginaceae, Poaceae, Polygonaceae, Ranunculaceae, Scrophulariaceae, Violaceae. The majority of weeds belonged to the Asteraceae family and included 7 species, of which Tripleurospermum perforatum (Mérat) M. Laínz was the most common. Irrespective of the soil tillage method, T. perforatum (Mérat) $\mathrm{M}$. Laínz, Capsella bursa-pastoris L., Veronica arvensis Murray ir Chenopodium album L. were most frequent in all experimental treatments: 46.0-134.0, 2.8-54.2, 7.2-20.0 and 6.0-11.6 plants $\mathrm{m}^{-2}$, respectively. Fallopia convolvulus L., Cerastium holosteoides Fr., Plantago major L. were also found in all treatments, but at lower abundance.

The soil weed seed bank was evaluated after the completion of the second crop rotation. According to Čiuberkis (2008), primary soil tillage of different intensity did not have any significant influence on the number of weed seeds in the soil after the completion of the first crop rotation.

Literature sources indicate that the soil seed banks are a key to understanding the dynamics of plant populations, species and ecosystems (Cabin et al., 1998). The composition of the soil seed bank depends on the plant communities appearing in a particular area both at the present moment and also in the past, as well as on the biological properties of plants. Changes in land-use and management practices influence the distribution of seeds in the soil and the established vegetation (Reine et al., 2004).

Evaluation of the influence of primary soil tillage methods and soil fertility improvement measures on the soil weed seed bank after the second rotation showed that the primary soil tillage had already had a significant influence $\left(\mathrm{F}_{\text {act. }}=33.2>\mathrm{F}_{\text {tabl.0.1 }}=5.01\right)$. In the deep ploughing treatment, the soil weed seed bank was significantly less abundant (15643 seeds $\mathrm{m}^{-2}$ ) compared with the shallow tillage and shallow ploughless tillage treatments (Table 2). In the shallow ploughing and shallow ploughless tillage treatments the soil weed seed bank was 1.5 and 2.2 times greater compared with conventional (deep ploughing) tillage treatments. 
Table 2. The influence of primary soil tillage methods and soil fertility improvement measures on the soil weed seed bank (seeds $\mathrm{m}^{-2}$ ).

Vèžaičiai, 2011

\begin{tabular}{|c|c|c|c|c|}
\hline \multirow{2}{*}{$\begin{array}{l}\text { Soil fertility improvement measures } \\
\text { (factor B) }\end{array}$} & \multicolumn{3}{|c|}{ Primary soil tillage (factor A) } & \multirow{2}{*}{$\begin{array}{l}\text { Mean of factor B } \\
\mathrm{LSD}_{05}=7939.274\end{array}$} \\
\hline & deep ploughing & shallow ploughing & shallow ploughless tillage & \\
\hline Plant residues & 15480 & 23478 & $25908^{*}$ & 21622 \\
\hline Plant residues + straw & 21280 & $27750^{*}$ & $31488 * *$ & 26839 \\
\hline Green manure $1^{\text {st }}$ cut + straw & 11438 & 17802 & $47092 * *$ & 25444 \\
\hline Green manure $2^{\text {nd }}$ cut + straw & 14204 & 19840 & $31944 * *$ & 21996 \\
\hline Farmyard manure $40 \mathrm{t} \mathrm{ha}^{-1}+$ straw & 15812 & $18408^{*}$ & $35328 * *$ & 26516 \\
\hline Mean of factor $\mathrm{ALSD}_{05}=6149.735$ & 15643 & $23456 * *$ & $34352 * *$ & \\
\hline
\end{tabular}

The soil weed seed bank did not depend on the soil fertility improvement measures. The differences were not essential. Although we did not establish any statistically significant influence of the soil fertility improvement measures on the soil weed seed bank, after ploughing down plant residues + straw or straw together with $40 \mathrm{t} \mathrm{ha}^{-1}$ of farmyard manure, the soil weed seed bank was by $4.6 \%$ to $19.0 \%$ greater than in the soil where only plant residues had been ploughed down or straw had been applied with the phytomass of red clover for the soil fertility improvement.

The influence of the soil tillage methods manifested itself not only directly, but also through the interaction with soil fertility improvement measures. Significantly more weed seeds was determined under shallow ploughing and using plant residues + straw, or straw together with $40 \mathrm{t} \mathrm{ha}^{-1}$ of farmyard manure.
Regardless of the chosen soil fertility improvement measures, in all treatments of shallow ploughless tillage, the soil weed seed bank was significantly greater (25908 47092 seeds $\mathrm{m}^{-2}$ ), compared with the conventional soil tillage method.

The diversity of weed seed species in the ploughlayer. The data of the analysis of variance showed that only the soil tillage method had a significant influence on the number of weed seed species in the ploughlayer $\left(\mathrm{F}_{\text {act. }}\right.$ $\left.=15.6>\mathrm{F}_{\text {tabl.0.1 }}=5.01\right)$. In the ploughlayer, significantly fewer weed seed species (on average $4.2 \mathrm{~m}^{-2}$ ) were found in the deep ploughing treatment, compared with the shallow ploughing and shallow ploughless tillage treatments (Table 3 ). In shallow ploughing and shallow ploughless tillage treatments, $25.5 \%$ and $41.5 \%$ more weed seed species were found than in the conventional (deep ploughing) treatment.

Table 3. The influence of primary soil tillage methods and soil fertility improvement measures on the diversity of weed seed species $\left(\mathrm{m}^{-2}\right)$ in the ploughlayer

Vèžaičiai, 2011

\begin{tabular}{ccccc}
\hline \multirow{2}{*}{$\begin{array}{c}\text { Soil fertility improvement measures } \\
\text { (factor B) }\end{array}$} & \multicolumn{3}{c}{ Primary soil tillage (factor A) } & Mean of factor B \\
\cline { 2 - 4 } LSD $_{05}=1.11$
\end{tabular}

* - significant at $P<0.05$, and ** - significant at $P<0.01$

The influence of soil fertility improvement measures on the number weed seed species in the ploughlayer was not distinct. Significantly more weed seed species were found after ploughing plant residues + straw or straw together with $40 \mathrm{t} \mathrm{ha}^{-1}$ of farmyard manure (on average $21.7 \%$ and $23.3 \%$ more than under ploughing only plant residues). Among other soil fertility improvement measures the differences were smaller than the least significant difference $\left(\mathrm{LSD}_{05}\right)$.

The analysis of the interaction between soil fertility improvement measures and soil tillage shows that the significantly higher number of weed seed species in the ploughlayer was found in deep and/or shallow ploughing treatment, when plant residues + straw or straw together with $40 \mathrm{t} \mathrm{ha}^{-1}$ of farmyard manure had been used to improve soil fertility. Regardless of the chosen soil fertility improvement measure, almost in all treatments of shallow ploughless tillage the number of weed seed species in the ploughlayer was significantly higher (5.6-7.4 weed seed species $\mathrm{m}^{-2}$ ), compared with the conventional soil tillage treatment.

During the study period, the following 20 weed seed species, belonging to 11 families, were found in the ploughlayer:Asteraceae, Brassicaceae, Caryophyllaceae, Chenopodiaceae, Euphorbiaceae, Fabaceae, Lamiaceae, Plantaginaceae, Poaceae, Polygonaceae, Violaceae.

It should be noted that the major part (78.0 $90.0 \%$ ) of the weed seed bank is composed of several weed 
species. The seeds of Chenopodium album L. account for the largest share in the seed bank (Grigas, 1995). The averaged data from the trial carried out in Vèžaičiai Branch of Lithuanian Research Centre for Agriculture and Forestry showed that the seeds of Chenopodium album L., Persicaria lapathifolia L., Fallopia convolvulus
L. and Viola arvensis Murray occurred in all treatments (Table 4). The seeds of Chenopodium album L. accounted for $34.3 \%$, Fallopia convolvulus L. for $18.4 \%$, Viola arvensis Murray for $12.2 \%$, Persicaria lapathifolia L. for $10.0 \%$ of the total soil seed bank.

Table 4. Relative abundance of weed seed species (\%) in the ploughlayer as influenced by the soil tillage methods Vèžaičiai, 2011

\begin{tabular}{|c|c|c|c|c|c|c|}
\hline \multirow{2}{*}{ Plant family } & \multirow{2}{*}{ Weed species } & \multicolumn{5}{|c|}{ Soil fertility improvement measures } \\
\hline & & $\mathrm{R}$ & $\mathrm{R}+\mathrm{S}$ & $\mathrm{GI}+\mathrm{S}$ & $\mathrm{GII}+\mathrm{S}$ & $\mathrm{M}+\mathrm{S}$ \\
\hline \multicolumn{7}{|c|}{ Deep ploughing } \\
\hline \multirow[t]{2}{*}{ Brassicaceae } & Capsella bursa-pastoris L. & - & 6.2 & - & 5.7 & 18.6 \\
\hline & Sinapsis arvensis L. & 1.6 & - & - & - & - \\
\hline \multirow[t]{2}{*}{ Polygonaceae } & Persicaria lapathifolia $\mathrm{L}$. & 5.0 & 10.0 & 14.0 & 1.9 & 13.6 \\
\hline & Fallopia convolvulus L. & 21.7 & 16.3 & 32.6 & 39.6 & 22.0 \\
\hline \multirow[t]{2}{*}{ Caryophyllaceae } & Spergula arvensis L. & - & 13.7 & 4.6 & - & 5.0 \\
\hline & Stellaria media (L.) Vill. & 5.0 & 8.8 & - & 1.9 & - \\
\hline Plantaginaceae & Plantago major L. & - & 1.3 & - & - & - \\
\hline Violaceae & Viola arvensis Murray & 15.0 & 10.0 & 14.0 & 20.7 & 11.9 \\
\hline Chenopodiaceae & Chenopodium album L. & 51.7 & 33.7 & 34.8 & 30.2 & 28.9 \\
\hline \multicolumn{7}{|c|}{ Shallow ploughing } \\
\hline \multirow[t]{3}{*}{ Brassicaceae } & Erysimum cheiranthoides L. & - & - & - & - & 1.9 \\
\hline & Capsella bursa-pastoris L. & 12.0 & 7.2 & 20.4 & 36.3 & 20.8 \\
\hline & Sinapsis arvensis L. & - & 2.7 & - & - & - \\
\hline \multirow[t]{2}{*}{ Polygonaceae } & Persicaria lapathifolia $\mathrm{L}$. & 5.5 & 15.4 & 1.4 & 7.5 & 2.8 \\
\hline & Fallopia convolvulus L. & 22.0 & 16.2 & 18.8 & 21.3 & 11.3 \\
\hline \multirow[t]{2}{*}{ Caryophyllaceae } & Scleranthus annuus L. & - & - & - & 1.2 & - \\
\hline & Spergula arvensis L. & 2.2 & 9.9 & - & 1.3 & 4.7 \\
\hline Asteraceae & Tripleurospermum perforatum (Merat.) M. Lainz. & - & - & - & 1.2 & 3.8 \\
\hline Poaceae & Poa anпua L. & - & - & 1.4 & - & - \\
\hline Fabaceae & Trifolium pratense $\mathrm{L}$. & 2.2 & - & 1.4 & - & - \\
\hline Plantaginaceae & Plantago major $\mathrm{L}$. & - & - & - & - & 1.9 \\
\hline Violaceae & Viola arvensis Murray & 19.8 & 21.6 & 29.0 & 5.0 & 13.2 \\
\hline Lamiaceae & Stachys palustris L. & - & - & - & 1.2 & - \\
\hline Chenopodiaceae & Chenopodium album $\mathrm{L}$. & 36.3 & 27.0 & 27.6 & 23.8 & 39.6 \\
\hline Euphorbiaceae & Euforbia helioscopia L. & - & - & - & 1.2 & - \\
\hline \multicolumn{7}{|c|}{ Shallow ploughless tillage } \\
\hline \multirow[t]{3}{*}{ Brassicaceae } & Erysimum cheiranthoides L. & 3.9 & 1.6 & 3.1 & 1.5 & 4.4 \\
\hline & Capsella bursa-pastoris L. & 4.9 & 12.2 & 24.3 & 33.3 & 20.3 \\
\hline & Sinapsis arvensis $\mathrm{L}$. & - & - & 0.5 & - & - \\
\hline \multirow[t]{4}{*}{ Polygonaceae } & Persicaria lapathifolia $\mathrm{L}$. & 15.7 & 12.2 & 12.9 & 10.6 & 13.0 \\
\hline & Fallopia convolvulus L. & 12.7 & 11.4 & 8.2 & 9.1 & 15.9 \\
\hline & Rumex acetosella $\mathrm{L}$. & - & - & 0.5 & - & - \\
\hline & Rumex crispus L. & 2.0 & - & - & - & - \\
\hline Caryophyllaceae & Spergula arvensis $\mathrm{L}$. & 13.7 & 22.8 & 6.2 & 4.5 & 3.6 \\
\hline \multirow[t]{2}{*}{ Asteraceae } & Tripleurospermum perforatum (Merat.) M. Lainz. & - & - & 1.5 & 3.8 & - \\
\hline & Sonchus arvensis $\mathrm{L}$. & - & - & 0.5 & 0.8 & - \\
\hline Violaceae & Viola arvensis Murray & 6.9 & 6.5 & 7.2 & 4.5 & 5.1 \\
\hline Lamiaceae & Galeopsis tetrahit $\mathrm{L}$. & - & - & - & 0.8 & - \\
\hline Chenopodiaceae & Chenopodium album $\mathrm{L}$. & 40.2 & 33.3 & 35.1 & 31.1 & 37.7 \\
\hline
\end{tabular}

$\mathrm{R}$ - plant residues, $\mathrm{R}+\mathrm{S}-$ plant residues + straw, $\mathrm{GI}+\mathrm{S}-$ green manure $1^{\text {st }}$ cut + straw, $\mathrm{GII}+\mathrm{S}-$ green manure $2^{\text {nd }}$ cut + straw, $\mathrm{M}+\mathrm{S}$ farmyard manure $40 \mathrm{tha}^{-1}+$ straw

The data of the statistical analysis of relative abundance of weed seed species suggest that a significant influence on the spread of seeds of Fallopia convolvulus L., Viola arvensis Murray, Persicaria lapathifolia L. was exerted by the soil tillage $\left(\mathrm{F}_{\text {act. }}=13.8>\mathrm{F}_{\text {tabl.0.1 }}=5.01\right.$,
$\mathrm{F}_{\text {act. }}=10.98>\mathrm{F}_{\text {tabl } 0.1}=5.01, \mathrm{~F}_{\text {act. }}=4.26>\mathrm{F}_{\text {tabl } 0.1}=5.01$, respectively) (Table 5). The seeds of $F$. convolvulus L. accounted for the significantly highest percentage of the total weed seed bank in the conventional soil tillage (deep ploughing) treatment. 
Table 5. The variance of the distribution of the weed seed species in the ploughlayer Vèžaičiai, 2011

\begin{tabular}{|c|c|c|c|c|}
\hline \multirow[t]{2}{*}{ Variance } & $\begin{array}{c}\text { Chenopodium } \\
\text { album }\end{array}$ & $\begin{array}{c}\text { Fallopia } \\
\text { convolvulus }\end{array}$ & $\begin{array}{c}\text { Viola } \\
\text { arvensis }\end{array}$ & $\begin{array}{l}\text { Persicaria } \\
\text { lapathifolia }\end{array}$ \\
\hline & $\mathrm{F}_{\mathrm{ac}}$ & $\mathrm{F}_{\mathrm{act}}$ & $\mathrm{F}_{\mathrm{act}}$ & $\mathrm{F}_{\mathrm{act}}$ \\
\hline Treatments & 1.85 & $3.46^{* *}$ & $3.72 * *$ & $2.26^{*}$ \\
\hline Primary soil tillage (factor A) & 1.85 & $13.8 * *$ & $10.98 * *$ & $4.26^{*}$ \\
\hline Soil fertility improvement measures (factor B) & $3.22 *$ & 1.25 & 1.59 & 1.69 \\
\hline Interaction of factors $\mathrm{A}$ and $\mathrm{B}$ & 1.17 & 1.98 & $2.97 * *$ & 2.05 \\
\hline
\end{tabular}

* - significant at $P<0.05$, and ** - significant at $P<0.01$

The differences among other soil tillage methods were smaller than the least significant difference $\left(\mathrm{LSD}_{05}\right)$. The seeds of Viola arvensis Murray were found in the shallow ploughing treatment; however, significant differences were found while comparing deep ploughing and shallow ploughing with shallow ploughless tillage. Because of the interaction of soil tillage and soil fertility improvement measures the highest counts of $V$. arvensis Murray seeds in the ploughlayer were found in the shallow ploughing and green manure $1^{\text {st }}$ cut + straw treatment. Shallow ploughless tillage had a more marked influence on the distribution Persicaria lapathifolia L. seeds.

Soil fertility improvement measures $\left(\mathrm{F}_{3 \mathrm{ct}}=3.22>\right.$ $\mathrm{F}_{\text {tabl } .0 .5}=2.54$ ) impacted on the distribution of Chenopodium album L. seeds. The significantly highest percentage of this species seeds from the total weed seed bank was identified in the treatment involving stubble ploughing. The weed seed bank's species composition differed from that of red clover sward, which was the last course of the rotation. Only $27-40 \%$ of the soil weed seed bank species were the same as in the red clover sward. These were annual archeophytes Ch. album L., F. convolvulus L., P. lapathifolia L. ir Capsella bursa-pastoris L.

\section{Conclusions}

1. The primary soil tillage had a significant influence on the weed incidence and soil weed seed bank in the crops of the second rotation. The greatest amount of weeds, in numbers as well as dry mass, was found in the crops of winter triticale and spring rape in the shallow ploughless tillage treatment, in the crops of spring barley in the shallow ploughing treatment, and in the sward of red clover in the deep and shallow ploughing treatments. The soil fertility improvement measures and their interaction with soil tillage methods did not have any significant influence on the amount of weeds and their dry matter mass in the rotation crops.

2 . In the deep ploughing treatment, the soil weed seed bank was significantly less abundant (15643 seeds $\mathrm{m}^{-2}$ ) than in the shallow ploughing or shallow ploughless tillage treatments. The influence of primary soil tillage methods manifested itself not only directly, but also through their interaction with soil fertility improvement measures. In the shallow ploughless tillage treatment, all the soil fertility improvement measures significantly increased the soil weed seed bank, compared with the conventional soil tillage treatment.

3. The shallow ploughing and shallow ploughless tillage treatments contained $25.5 \%$ and $41.5 \%$ more weed seed species in the soil, compared with the conventional soil tillage (deep ploughing) treatment. The amount of weed seed species was increased by ploughed in residues + straw and/or straw together with $40 \mathrm{t} \mathrm{ha}^{-1}$ of farmyard manure. This treatment contained by on average $21.7 \%$ and $23.3 \%$ more weed seed species, compared with that with ploughed in residues only).
4. Polygonaceae Juss, Chenopodiaceae Vent. and Violaceae L. were most numerous in the ploughlayer's weed seed bank. The seeds of Persicaria lapathifolia L., Fallopia convolvulus L., Chenopodium album L. and Viola arvensis Murray were identified in all experimental treatments.

5. Only soil tillage had a significant effect on the distribution of $F$. convolvulus L. and P. lapathifolia $\mathrm{L}$. seeds. The distribution of $V$. arvensis Murray seeds was significantly impacted by the soil tillage and its interaction with soil fertility improvement measures, while that of Ch. album L. seeds was significantly influenced by only soil fertility improvement measures.

6 . The weed seed bank's species composition differed from that of red clover sward, which was the last course of the rotation. Only $27-40 \%$ of the soil weed seed bank species were the same as in the red clover sward. These were annual archeophytes Ch. album L., F. convolvulus L., P. lapathifolia L. and Capsella bursapastoris $\mathrm{L}$.

\section{Acknowledgments}

The paper presents research findings, obtained through the long-term research programme "Productivity and sustainability of agricultural and forest soils" implemented by Lithuanian Research Centre for Agriculture and Forestry.

Received 19112012

Accepted 14122012

\section{References}

Arlauskienė A., Maikštėnienè, S. 2005. The effect of legume preceding crop biomass on weed infestation in cereals. Vagos, 66 (19): 7-16 (in Lithuanian)

Auškalnienè O. 2006. The critical period of weed competition in spring barley and maize crops. Vagos, 71 (24): 7-12 (in Lithuanian)

Auškalnienė O., Auškalnis A. 2009. The influence of tillage system on diversities of soil weed seed bank. Agronomy Research, 7 (special iss. 1): 156-161

Bàrberi P., Lo Cascio B. 2001. Long-term tillage and crop rotation effects on weed seedbank size and composition. Weed Research. 41 (4): 325-340 http://dx.doi.org/10.1046/j.1365-3180.2001.00241.x

Cabin R. J., Mitchell R. J., Marshall D. L. 1998. Do surface plant and soil seed bank populations differ genetically? A multipopulation study of the desert mustard Lesquerella fendleri (Brassicaceae). American Journal of Botany, 85: 1098-1109 http://dx.doi.org/10.2307/2446343

Čiuberkis S. 2008. The influence of traditional and reduced soil tillage on crop weed infestation in crop rotation. Vagos, 79 (32): 37-42 (in Lithuanian)

Ciuberkis S. 2009. Effect of soil pH and nutrient content on weed infestation on spring barley crop. Vagos, 84 (37): 12-16 (in Lithuanian)

Deveikytė I., Semaškienè R., Leistrumaitè A. 2008. The competition between cereals and weeds under the conditions 
of organic agriculture. Zemdirbyste-Agriculture, 95 (2): 3-15 (in Lithuanian)

Grigas A. 1995. Soil seed bank in cultivated and uncultivated land. Žemdirbystè: Lietuvos žemdirbystès instituto mokslo darbai, 49: 90-111 (in Lithuanian)

Gselman A., Kramberger B. 2004. Longevity and vertical distribution of dandelion (Taraxacum officinale F. Weber.) seeds in meadow soil. Grassland Science in Europe, 9: $252-254$

Janicka M. 2006. Species composition of the soil seed bank in comparison with the floristic composition of meadow sward. Grassland Science in Europe, 11: 200-202

Jursík M., Holec J., Soukup J., Venclová V. 2010. Seasonal emergence of selected summer annual weed species in dependence on soil temperature. Plant, Soil and Environment, 56 (9): 444-450

Menalled F. D., Gross K. L., Hammond M. 2001. Weed aboveground and seedbank community responses to agricultural management systems. Ecological Applications, 11 (6): 1586-1601 httn://dx.doi.org/10.1890/10510761(2001)011[1586:WAASCR]2.0.CO;2

Moonen A. C., Barberi P. 2004. Size and composition of the weed seedbank after 7 years of diferent cover-crop-maize management systems. Weed Research, 44 (3): 163-177 http://dx.doi.org/10.1111/j.1365-3180.2004.00388.x

Reine R., Chocarro C., Fillat F. 2004. Soil seed bank and management regimes of semi-natural mountain meadow communities. Agriculture, Ecosystems and Environment, 104: $567-575$

http://dx.doi.org/10.1016/j.agee.2004.01.024
Skuodienè R., Repšienė R. 2009. The effects of organic fertilisers and liming on segetal flora in a sustainable crop rotation on an acid soil. Zemdirbyste-Agriculture, 96 (4): 154-169 (in Lithuanian)

Stancevičius A., Špokienė N., Trečiokas K., Raudonius S., Klimas E. 1996. Verstuvinio ir beverstuvinio žemès dirbimo palyginimas. Žemdirbystès mokslo dabartis ir ateitis: mokslinès konferencijos pranešimai. Lithuanian Institute of Agriculture, p. 79-85 (in Lithuanian)

Swanton C. J., Shrestha A., Knezevic S. Z., Roy R. C., BallCoelho B. R. 2000. Influence of tillage type on vertical weed seedbank distribution in a sandy soil. Canadian Journal of Plant Science. 80 (2): 455-457 http://dx.doi.org/10.4141/P99-020

Šimanskaite D. 2002. Effect of different soil tillage and sowing methods on soil and yield. Zemdirbyste-Agriculture, 79 (3): 131-138 (in Lithuanian)

Tarakanovas P., Raudonius S. 2003. Agronominių tyrimų duomenų statistinè analizè taikant kompiuterines programas ANOVA, STAT, SPLIT-PLOT iš paketo SELEKCIJA ir IRRISTAT. Akademija, Kauno r., 58 p. (in Lithuanian)

Velykis A., Maikštenienè S. 1995. The effect of soil loosening and presowing tillage on mechanical composition of heavy soils. Žemès ūkio mokslai, 3: 18-23 (in Lithuanian)

Velykis A., Satkus A. 2003. Meliorantų ir žemès dirbimo ịtaka pasèlių piktžolètumui ir augalų derliui. Žemès ūkio mokslai, 4: 57-68 (in Lithuanian)

ISSN 1392-3196

Zemdirbyste-Agriculture, vol. 100, No. 1 (2013), p. 25-32

UDK 631.4:631.582:632.51 / DOI 10.13080/z-a.2013.100.004

\title{
Pagrindinio žemès dirbimo įtaka dirvožemio sẻklų bankui ir piktžolėtumui javų bei žolių sẻjomainoje
}

\author{
R. Skuodienè ${ }^{1}$, D. Karčauskienė $\dot{1}^{1}$, S. Čiuberkis ${ }^{1}$, R. Repšienè ${ }^{1}$, D. Ambrazaitienè $\dot{1}^{1,2}$ \\ ${ }^{1}$ Lietuvos agrarinių ir miškų mokslų centro Vèžaičių filialas \\ ${ }^{2}$ Klaipedos universitetas
}

\section{Santrauka}

Lietuvos agrarinių ir miškų mokslų centro Véžaičių filiale 2008-2011 m. vykdytas lauko bandymas, siekiant nustatyti ịvairių žemès dirbimo būdų (gilus arimas, seklus arimas, seklus neariminis dirbimas) ir dirvožemio derlingumą gerinančiu priemonių (augalų liekanos, augalų liekanos + šiaudai, I pjūties žalioji trąša + šiaudai, II pjūties žalioji trąša + šiaudai, mėšlas $40 \mathrm{t} \mathrm{ha}^{-1}+$ šiaudai) įtaką dirvožemio užterštumui piktžolių sèklomis bei sėjomainos piktžolètumui. Bandymo dirvožemis - nepsotintasis sekliai glëjiškas balkšvažemis (JIg8-n), granuliometrinè sudètis - smèlingas priemolis.

Visais tyrimu metais sėjomainos pasėliu piktžolètumui ir dirvožemio užterštumui piktžoliu sẻklomis esminę itaka turejjo rudeninis žemės dirbimas. Žieminių kvietrugių ir vasarinių rapsų pasėliuose didžiausias piktžolių kiekis bei jų sausujų medžiagų masè nustatyta taikant seklų neariminị dirbimo būdą, vasarinių miežių pasėlyje - seklų arimą, o raudonujų dobilų žolyne - gilų ir seklų arimą. Skirtingos dirvožemio derlingumą palaikančios priemonès ir jų sąveika su žemès dirbimo būdais esminès įtakos sėjomainos pasėlių piktžolètumui neturèjo. Piktžolių sẻklų kiekis dirvožemyje taikant seklų arimą ir seklų neariminị dirbimą nustatytas 1,5 ir 2,2 karto didesnis nei dirbant tradiciniu būdu (giliai ariant). Žemès dirbimo būdu įtaka pasireiškẻ ne tik tiesiogiai, bet ir per sąveiką su dirvos derlingumą palaikančiomis priemonèmis. Nepriklausomai nuo pasirinktos dirvos derlingumą palaikančios priemonės, taikant seklų neariminị dirbimą visais atvejais piktžolių sẻklų kiekis dirvožemyje nustatytas iš esmès didesnis, lyginat su tradiciniu žemès dirbimo būdu.

Taikant seklų arimą ir seklų neariminị dirbimą, dirvožemyje ịvairių rūšių piktžolių sẻklų nustatyta 25,5 ir 41,5\% daugiau nei dirbant tradiciniu būdu (giliai ariant). Visuose variantuose rasta Chenopodium album L., Persicaria lapathifolia L., Fallopia convolvulus L. ir Viola arvensis Murray sėklų. F. convolvulus L. ir P. lapathifolia L. sėklų paplitimui esminès įtakos turejjo tik žemès dirbimas, V. arvensis Murray - žemės dirbimas ir jo sąveika su dirvos derlingumą palaikančiomis priemonėmis, o Ch. album L. sėklų paplitimą lèmè tik dirvos derlingumą palaikančios priemonès (organinès trąšos).

Reikšminiai žodžiai: dirvos derlingumą palaikančios priemonès, piktžolių kiekis ir jų masè, sèjomaina, sėklų bankas, žemès dirbimas rudenį. 